\title{
Estimation of the postmortem interval using GAPDH mRNA in skin and heart tissues of albino rats at different environmental conditions
}

\author{
Hoda Abdelmagid Elghamry ${ }^{1}$, Fatma Mohamed Hassan ${ }^{1 *}$ D, Marwa Issak Mohamed ${ }^{1}$, Dina Sabry Abdelfattah ${ }^{2}$ \\ and Aly Gamaleldin Abdelaal ${ }^{1}$
}

\begin{abstract}
Background and objectives: Post-mortem interval (PMI) estimation is an important topic in forensic sciences. Several methods have been used to determine the PMI, but most of these provide inaccurate results under certain conditions. The degradation of RNA after death has been reported to be a useful tool for PMI estimation. This study aimed to evaluate the potential use of skin and heart GAPDH mRNA levels for determining the PMI under different environmental conditions.

Methods: Seventy-eight adult female albino rats were sacrificed by cervical dislocation. Then, rats divided into the control group and four experimental groups left under different conditions (in ambient air at $30^{\circ} \mathrm{C}$ and at $6{ }^{\circ} \mathrm{C}$, buried in sand and submerged under water at an air temperature of $30^{\circ} \mathrm{C}$ ). The skin and heart samples were obtained at different time points $(0,24,48$, and $96 \mathrm{~h}$ post-mortem), and the GAPDH mRNA level in each sample was detected by qRT-PCR.

Results: The GAPDH mRNA levels decreased with increasing PMI in all study groups. There were significant negative correlations between the heart GAPDH mRNA level and the time interval in all studied groups, while the skin GAPDH mRNA level only showed negative correlations under certain conditions.

Conclusion: The GAPDH mRNA level in rat heart and skin could be a useful marker for PMl estimation under various environmental conditions.
\end{abstract}

Keywords: Post-mortem interval, Forensic sciences, GAPDH, mRNA, Environment

\section{Background}

Determination of the time of death is a vital question in any forensic casework. Precise estimation of the post-mortem interval (PMI) is crucial at both the civil and criminal levels. The PMI assists in proving and excluding suspects, identifying the exact time of a crime, and solving some legal problems related to inheritance (Elghamry et al. 2017).

Several approaches have been used to estimate the time since death, including physical, biochemical, and

\footnotetext{
*Correspondence: fatmahasan.2010@yahoo.com

${ }^{1}$ Forensic Medicine and Clinical Toxicology, Faculty of Medicine, Cairo University, Kasr Alainy Street, Cairo 11562, Egypt

Full list of author information is available at the end of the article
}

entomological methods (Sato et al. 2015). However, these methods are of limited value. Many environmental factors, such as temperature and insect activity, and individual factors, such as age and sex, have a strong influence on these methods (Ali, et al. 2017).

The great progress in molecular biology has encouraged the development of alternative approaches for PMI evaluation using the degradation of biological materials, such as proteins, DNA, and RNA (Lv et al. 2016).

Many studies have investigated the degradation of RNA in estimating the PMI in different tissues using several mRNA markers, including $\beta$-actin, GAPDH, and IL-1 $\beta$ (Wen-Can et al. 2014; Sampaio-Silva et al. 2013; Liu et al. 2011; Inoue et al. 2002). However, the effect of 
different environmental conditions on the reliability of this method has not yet been explored.

This study aimed to evaluate the potential use of skin and heart GAPDH mRNA levels determined by qRT-PCR for estimating the PMI of rats exposed to different environmental conditions.

GAPDH was selected as the target marker because it is a housekeeping gene that has shown time-dependent quantitative changes with the PMI in several studies (Elghamry et al. 2017; Lv et al. 2014; Sampaio-Silva et al. 2013; Inoue et al. 2002).

\section{Materials and methods \\ Animal protocol}

Seventy-eight adult female albino rats weighing 120$150 \mathrm{~g}$ were sacrificed by cervical dislocation. Then, the rats were divided into five groups. Group 0 (the control) comprised of six rats from which the skin and heart samples were taken immediately after sacrifice (at the 0 time interval). Groups 1, 2, 3, and 4 each comprised of 18 rats. Sacrificed rats in groups 1, 2, and 3 were left in ambient air, buried in sand, or submerged underwater at an average air temperature of $30^{\circ} \mathrm{C}$, respectively, while rats in group 4 were left in a refrigerator at $6^{\circ} \mathrm{C}$. The skin and heart samples were obtained at three different time points: $24 \mathrm{~h}, 48 \mathrm{~h}$, and $96 \mathrm{~h}$ post-mortem (six rats for each time point).

\section{Total RNA extraction}

Total RNA was isolated using the Total RNA Extraction Kit (GF-1, cat. no. GF-TR-050, Malaysia), and then analyzed for both quantity and quality with Beckman dual spectrophotometer (USA).

\section{qRT-PCR}

qRT-PCR assays were performed using ViPrime One Step RT-qPCR 2X SyGreen Mix (HRox, cat. no QR8602-100, Malaysia) on a StepOne Real-Time PCR Applied Biosystems detection system with version 3.1 software (StepOne ${ }^{\mathrm{rm}}$, USA). We used $5 \mu \mathrm{L}$ of total RNA and $1 \mu \mathrm{L}$ of both primers specific to each gene. The primer sequences for each gene are shown in Table 1. A negative control sample was included. The thermal cycler conditions were as follows: 1 cycle of reverse transcription for $10 \mathrm{~min}$ at $55^{\circ} \mathrm{C}$ and initial activation for 2 min at $95^{\circ} \mathrm{C}$, and 40 cycles of denaturing at $95^{\circ} \mathrm{C}$ for $5 \mathrm{~s}$, followed by annealing and extension at $60^{\circ} \mathrm{C}$ for $1 \mathrm{~min}$.

$\beta$-Actin was chosen as a reference gene because it is one of the most common housekeeping genes used for normalizing gene expression levels, and its transcription level remains relatively constant in response to experimental manipulation in most tissues (Li et al. 2010).

\section{Calculation of relative quantification (RQ) (relative expression)}

After the RT-PCR run, the data are expressed in cycle threshold $(\mathrm{Ct})$. The PCR data sheet included $\mathrm{Ct}$ values of the assessed gene (GAPDH) and the reference gene $(\beta$-actin). Therefore, target gene expression was assessed and related to the reference gene as follows:

$$
\begin{gathered}
\Delta \mathrm{Ct}_{\text {sample }}=\mathrm{Ct}_{\text {assessed gene }}-\mathrm{Ct}_{\text {reference gene }} \\
\Delta \Delta \mathrm{Ct}=\Delta \mathrm{Ct}_{\text {sample }}-\mathrm{Ct}_{\text {control gene }}
\end{gathered}
$$

RQ was then calculated according to the following equation:

$$
\mathrm{RQ}=2^{-(\Delta \Delta \mathrm{Ct})}
$$

\section{Statistical analysis}

Data were coded and entered using SPSS (Statistical Package for the Social Sciences) version 22 software. Data are summarized using the mean and standard deviation. Comparisons between groups were performed using the non-parametric Kruskal-Wallis and MannWhitney tests (Chan, 2003a). Correlations between variables were assessed using Spearman's correlation coefficients $\left(r_{\mathrm{s}}\right)$ (Chan, 2003b). $P$ values equal to or less than 0.05 were considered statistically significant.

\section{Results}

The mean relative skin and heart GAPDH mRNA levels after the different time intervals in the studied groups are shown in Figs. 1 and 2, respectively. The mean skin GAPDH mRNA levels after the different studied post-mortem time intervals showed statistically significant

Table 1 Primers of target and reference genes

\begin{tabular}{lll}
\hline Gene & Primer sequence & GenBank accession number \\
\hline GAPDH (target gene) & Forward primer: & NG_028301.2 \\
& 5-'CACCCTGTTGCTGTAGCCATATTC-3' & Reverse primer: \\
& 5'-GACATCAAGAAGGTGGTGAAGCAG-3' & J00691 \\
$\beta$-actin (reference gene) & Forward primer: & \\
& 5'-TGTTGCCCTGTATGCCTCT-3' & \\
& Reverse primer: & \\
& 5'-TAATGTCACGCACGATTCC-3' & \\
\hline
\end{tabular}




\section{Skin}

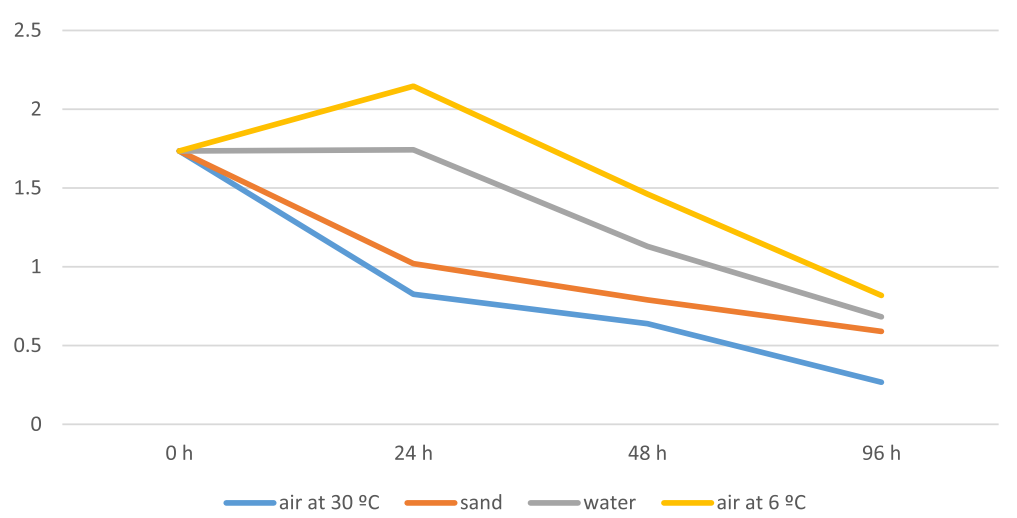

Fig. 1 Mean skin GAPDH relative expression levels in the studied groups after different time intervals

differences in groups 1 and 3 (Table 2), while the heart GAPDH levels showed statistically significant differences in all four groups (Table 3).

Pairwise comparisons at each time point of the skin GAPDH mRNA level in groups 1 and 3, and the heart GAPDH mRNA level in all four groups show significant differences between the mean GAPDH levels in the control group $(0 \mathrm{~h})$ and those at $96 \mathrm{~h}$ in all groups. There were also differences between these levels at $24 \mathrm{~h}$ and those at $96 \mathrm{~h}$ intervals, except for the skin GAPDH level in group 1, as well as differences between the GAPDH levels in the control group and those at $48 \mathrm{~h}$, except for the skin GAPDH level in group 3 and the heart GAPDH level in group 1. There were non-significant differences between the mean GAPDH levels in the control group and those at $24 \mathrm{~h}$ for all groups, between the levels at 24 $\mathrm{h}$ and $48 \mathrm{~h}$, except for the heart level in group 4, and between the levels at $48 \mathrm{~h}$ and $96 \mathrm{~h}$, except for the skin level in group 1 and the heart levels in groups 1 and 3 (Tables 4 and 5).
Correlations between the heart GAPDH mRNA levels and the time intervals were statistically significant in all four groups, and those between the skin GAPDH mRNA levels and the time intervals were significant in groups 3 and 4 (Table 6).

\section{Discussion}

The estimation of time since death is one of the most essential and controversial topics in forensic medicine. If accurately estimated, the PMI can solve many medicolegal mysteries (Garg and Garg, 2010).

The post-mortem degradation of RNA is inevitable and may provide an accurate tool for PMI determination if there is a correlation between the residual amount of RNA and the elapsed time (Song et al. 2012).

In the present study, we explored the relationship between the PMI and the mRNA level in heart and skin tissues under different environmental conditions. We tried to simulate most of the conditions under which a body might be left post-mortem, i.e., in the air, buried in

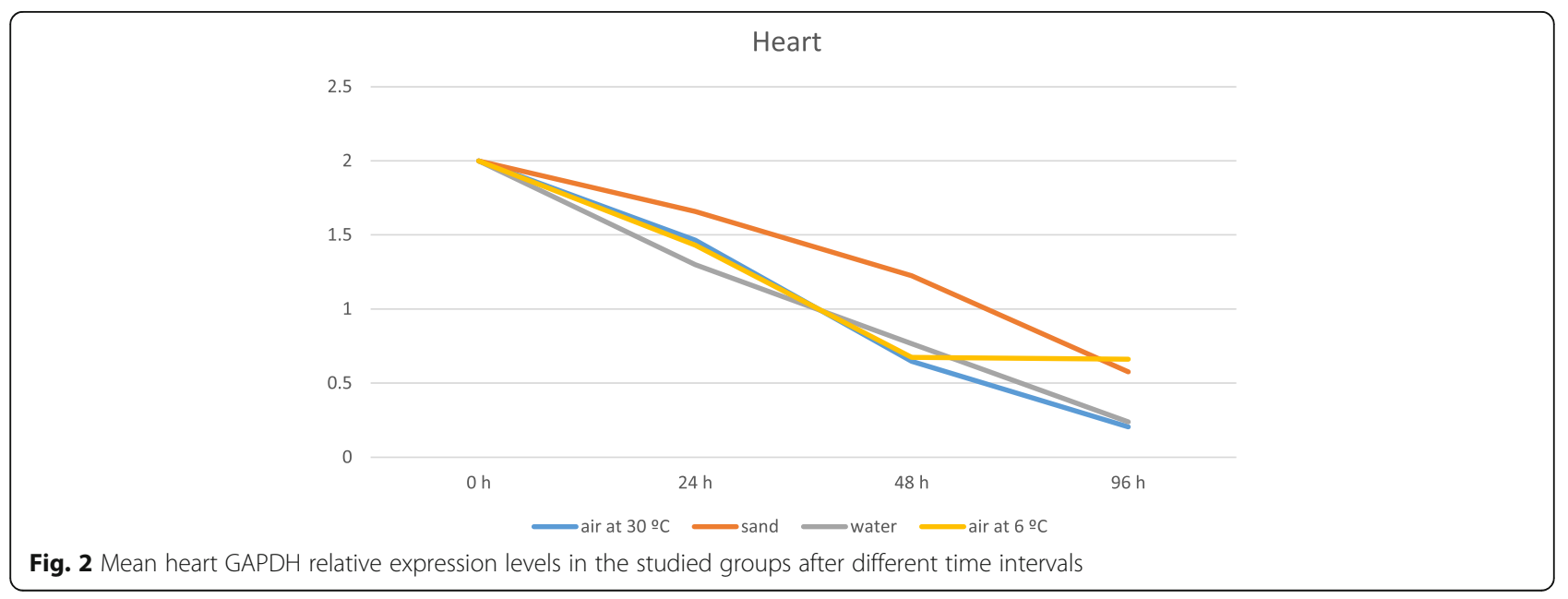


Table 2 Comparison of the mean skin GAPDH levels at different postmortem time points in the studied groups

\begin{tabular}{|c|c|c|c|c|c|}
\hline & \multicolumn{4}{|l|}{ Time (h) } & \multirow{2}{*}{$\begin{array}{l}P \\
\text { value }\end{array}$} \\
\hline & Zero & $24 \mathrm{~h}$ & $48 \mathrm{~h}$ & $96 \mathrm{~h}$ & \\
\hline \multirow[t]{2}{*}{ Group 1 (air at $30^{\circ} \mathrm{C}$ ) } & 1.734 & 0.826 & 0.640 & 0.267 & \multirow[t]{2}{*}{$0.00^{*}$} \\
\hline & $0 \pm .919$ & $0 \pm .668$ & $0 \pm .292$ & $0 \pm .134$ & \\
\hline \multirow[t]{2}{*}{ Group 2 (sand at $30^{\circ} \mathrm{C}$ air temperature) } & 1.734 & 1.027 & 0.797 & 0.598 & \multirow[t]{2}{*}{0.06} \\
\hline & $0 \pm .919$ & $0 \pm .556$ & $0 \pm .542$ & $0 \pm .154$ & \\
\hline \multirow[t]{2}{*}{ Group 3 (water at $30^{\circ} \mathrm{C}$ air temperature) } & 1.734 & 1.742 & 1.130 & 0.683 & \multirow[t]{2}{*}{$0.03^{*}$} \\
\hline & $0 \pm .919$ & $0 \pm .567$ & $0 \pm .472$ & $0 \pm .393$ & \\
\hline \multirow[t]{2}{*}{ Group 4 (air at $6^{\circ} \mathrm{C}$ ) } & 1.734 & 2.146 & 1.462 & 0.818 & \multirow[t]{2}{*}{0.07} \\
\hline & $0 \pm .919$ & \pm 1.324 & $0 \pm .704$ & $0 \pm .201$ & \\
\hline
\end{tabular}

${ }^{*} P$ value is statistically significant

sand, or submerged under water. The air medium was examined at two different temperatures: $30^{\circ} \mathrm{C}$ and $6{ }^{\circ} \mathrm{C}$.

In this study, the highest GAPDH levels relative to the control $(0 \mathrm{~h})$ for both organs in all study groups were observed at $24 \mathrm{~h}$, while the lowest levels were observed at $96 \mathrm{~h}$. At $24 \mathrm{~h}$, the skin GAPDH level in group 4 was non-significantly higher than that of the control.

Similarly, a number of studies have detected the loss of mRNA transcripts with increasing PMI (Bauer et al. 2003; Fontanesi et al. 2008; Birdsill et al. 2011). This decrease in GAPDH expression is due to the degradation of RNA after death by ribonucleases present in cells and/or originating from bacteria or other environmental contamination, as well as the influence of environmental factors, such as pH, UV light, and humidity (Bauer, 2007).

Regarding the increased expression at $24 \mathrm{~h}$ in the skin in group 4, Young et al. (2013) reported the same increase in a study of gene expression in porcine tooth pulp, and they related that increase to the relative difference in degradation rate between the target and reference genes and not due to an actual increase in mRNA quantity.

Regarding comparisons of the mean GAPDH levels after different post-mortem time intervals in the studied groups, there were statistically significant differences in the heart in the four groups and the skin in groups 1 and 3. This result is concordant with those of Partemi et al. (2010), who reported a significant difference in the NOS3 mRNA level of cardiac samples between long (from 36 to $120 \mathrm{~h}$ ) and short (from 0.66 to $2.7 \mathrm{~h}$ ) PMI groups. Additionally, Ali et al. (2017) observed a significant decrease in skin LCE1C mRNA expression.

Regarding pairwise comparisons of skin and heart GAPDH mRNA levels in the studied groups for each time point, we observed significant differences generally between alternating time points and not between successive time points, with the few exceptions mentioned before. Similar results were obtained by Ali et al. 2017, who studied LCE1C expression in skin specimens and observed significant differences in LCE1C expression between the third and fifth, third and sixth, and fourth and sixth days, but not between the third and fourth, fourth and fifth, or fifth and sixth days.

We speculate that the rate of mRNA degradation must reach a certain level to cause a significant change in the GAPDH level between time points. This degradation level was achieved between alternating time points, not necessarily between successive time points, with a few

Table 3 Comparison of the mean heart GAPDH levels at different postmortem time points in the studied groups

\begin{tabular}{|c|c|c|c|c|c|}
\hline & \multicolumn{4}{|l|}{ Time (h) } & \multirow{2}{*}{$\begin{array}{l}P \\
\text { value }\end{array}$} \\
\hline & Zero & $24 \mathrm{~h}$ & $48 \mathrm{~h}$ & $96 \mathrm{~h}$ & \\
\hline \multirow[t]{2}{*}{ Group 1 (air at $30^{\circ} \mathrm{C}$ ) } & 2.000 & 1.465 & 0.647 & 0.205 & \multirow[t]{2}{*}{$0.00^{*}$} \\
\hline & $0 \pm .936$ & $0 \pm .466$ & $0 \pm .572$ & $0 \pm .168$ & \\
\hline \multirow[t]{2}{*}{ Group 2 (sand at $30^{\circ} \mathrm{C}$ air temperature) } & 2.000 & 1.658 & 1.225 & 0.576 & \multirow[t]{2}{*}{$0.00^{*}$} \\
\hline & $0 \pm .936$ & $0 \pm .422$ & $0 \pm .585$ & $0 \pm .341$ & \\
\hline \multirow[t]{2}{*}{ Group 3 (water at $30^{\circ} \mathrm{C}$ air temperature) } & 2.000 & 1.299 & 0.766 & 0.238 & \multirow[t]{2}{*}{$0.00^{*}$} \\
\hline & $0 \pm .936$ & $0 \pm .740$ & $0 \pm .326$ & $0 \pm .133$ & \\
\hline \multirow[t]{2}{*}{ Group 4 (air at $6^{\circ} \mathrm{C}$ ) } & 2.000 & 1.430 & 0.673 & 0.661 & \multirow[t]{2}{*}{$0.02^{*}$} \\
\hline & $0 \pm .936$ & $0 \pm .554$ & $0 \pm .668$ & $0 \pm .928$ & \\
\hline
\end{tabular}

${ }^{*} P$ value is statistically significant 
Table 4 Pairwise comparisons for each time point of the skin GAPDH level in groups 1 and 3

\begin{tabular}{llll}
\hline Time periods & & $\begin{array}{l}\text { Group 1 } \\
\text { (air at } 30^{\circ} \mathrm{C} \text { ) }\end{array}$ & $\begin{array}{l}\text { Group 3 } \\
\text { (air at 6 }{ }^{\circ} \mathrm{C} \text { ) }\end{array}$ \\
\hline Zero & $24 \mathrm{~h}$ & 0.10 & 0.87 \\
zero & $48 \mathrm{~h}$ & $0.01^{*}$ & 0.26 \\
zero & $96 \mathrm{~h}$ & $0.00^{*}$ & $0.03^{*}$ \\
$24 \mathrm{~h}$ & $48 \mathrm{~h}$ & 0.74 & 0.10 \\
$24 \mathrm{~h}$ & $96 \mathrm{~h}$ & 0.19 & $0.01^{*}$ \\
$48 \mathrm{~h}$ & $96 \mathrm{~h}$ & $0.02^{*}$ & 0.15 \\
\hline
\end{tabular}

${ }^{*} P$ value is statistically significant

exceptions due to the different rates of tissue degradation in response to different environments.

Regarding the correlations between the GAPDH level and the time points in the studied groups, there were significant negative correlations for the heart in the four groups and the skin in groups 3 and 4 . The heart results are in accordance with those reported by Inoue et al. 2002, who assessed the GAPDH mRNA levels in dead rat organs for 7 days post-mortem at $20^{\circ} \mathrm{C}$ and found that the $\mathrm{Ct}$ values for GAPDH mRNA in the heart increased linearly with increasing PMI. Additionally, Liu et al. (2011) reported that changes in the Ct values of heart $\beta$-actin mRNA in rats showed a good linear relationship with the PMI at a temperature of $20^{\circ} \mathrm{C}$.

In contrast, Sampaio-Silva et al. (2013) reported no significant correlations between the analyzed transcripts in the heart samples and the PMI, and Partemi et al. (2010) studied the post-mortem expression of five genes in human cardiac tissues and concluded that mRNA levels are independent of the PMI. Additionally, Deng et al. 2013 reported that the $\Delta \mathrm{Ct}$ values of heart HIF-1- $\alpha$ and $\beta$-actin mRNAs in tissues kept at $4{ }^{\circ} \mathrm{C}$ showed no correlation with the PMI.

Concerning the skin results, Song et al. (2012) observed a significant correlation between the elapsed time and the quantity of mRNA transcripts in skin samples from modified radical mastectomy specimens. Additionally, Pan et al. (2014) observed a good linear relationship between the PMI and $\beta$-actin and GAPDH mRNA levels in rat skin at

Table 5 Pairwise comparisons for each time point of the heart GAPDH level in the four studied groups

\begin{tabular}{llllll}
\hline \multicolumn{2}{l}{ Time periods } & $\begin{array}{l}\text { Group 1 } \\
\text { (air at } 30^{\circ} \mathrm{C} \text { ) }\end{array}$ & $\begin{array}{l}\text { Group 2 } \\
\text { (sand) }\end{array}$ & $\begin{array}{l}\text { Group 3 } \\
\text { (water) }\end{array}$ & $\begin{array}{l}\text { Group 4 } \\
\text { (air at 6 }{ }^{\circ} \mathrm{C} \text { ) }\end{array}$ \\
\hline Zero & $24 \mathrm{~h}$ & 0.42 & 0.20 & 0.26 & 0.26 \\
Zero & $48 \mathrm{~h}$ & 0.15 & $0.03^{*}$ & $0.02^{*}$ & $0.05^{*}$ \\
Zero & $96 \mathrm{~h}$ & $0.01^{*}$ & $0.00^{*}$ & $0.02^{*}$ & $0.00^{*}$ \\
$24 \mathrm{~h}$ & $48 \mathrm{~h}$ & 0.20 & 0.20 & 0.07 & $0.02^{*}$ \\
$24 \mathrm{~h}$ & $96 \mathrm{~h}$ & $0.00^{*}$ & $0.00^{*}$ & $0.05^{*}$ & $0.00^{*}$ \\
\hline $8 \mathrm{~h}$ & $96 \mathrm{~h}$ & $0.03^{*}$ & $0.03^{*}$ & 0.74 & 0.15 \\
\hline
\end{tabular}

${ }^{*} P$ value is statistically significant
Table 6 Spearman's correlation analysis between the time intervals and the skin and heart GAPDH levels in the different groups

\begin{tabular}{llll}
\hline & & & Time $(\mathrm{h})$ \\
\hline Group 1 (air at $30^{\circ} \mathrm{C}$ ) & Skin & $r_{\mathrm{s}}$ & -0.42 \\
& & $P$ value & 0.08 \\
& Heart & $r_{\mathrm{s}}$ & -0.77 \\
& & $P$ value & $<0.00^{*}$ \\
Group 2 (sand at $30^{\circ} \mathrm{C}$ & Skin & $r_{\mathrm{s}}$ & -0.25 \\
air temperature) & & $P$ value & 0.30 \\
& Heart & $r_{\mathrm{s}}$ & -0.74 \\
& & $P$ value & $<0.00^{*}$ \\
Group 3 (water at 30 ${ }^{\circ} \mathrm{C}$ & Skin & $r_{\mathrm{s}}$ & -0.66 \\
air temperature) & & $P$ value & $0.00^{*}$ \\
& Heart & $r_{\mathrm{s}}$ & -0.74 \\
& & $P$ value & $<0.00^{*}$ \\
Group 4 (air at $6{ }^{\circ} \mathrm{C}$ ) & Skin & $r_{\mathrm{s}}$ & -0.56 \\
& & $P$ value & $0.01^{*}$ \\
& & $r_{\mathrm{s}}$ & -0.48 \\
& Heart & $P$ value & $0.04^{*}$ \\
\hline
\end{tabular}

${ }^{*} P$ value is statistically significant

$4{ }^{\circ} \mathrm{C}$; however, contrary to our results, they observed a good linear relationship between the PMI and the $\beta$-actin and GAPDH mRNA levels in rat skin at $15^{\circ} \mathrm{C}$, and observed an $\mathrm{S}$ curve-type relationship between the levels of the two markers and the PMI at $35^{\circ} \mathrm{C}$.

Unfortunately, no previously reported studies have examined the correlation between heart or skin mRNA levels and the PMI in bodies buried in sand or submerged under water. Elghamry et al. (2017) studied the expression of GAPDH mRNA under such conditions but in brain tissues and reported a significant correlation with the PMI. The different results for the different tissues can be related to the fact that the integrity of RNA differs among different tissues and organs post-mortem (Sampaio-Silva et al. 2013).

\section{Conclusion}

This research suggests that the skin and heart GAPDH mRNA levels could be valuable tools for PMI estimation under several environmental conditions, potentially providing an additional method to current approaches of PMI estimation. However, this method should be further evaluated in future studies including human tissues and exploring the influence of various factors (e.g., age, sex, and cause of death).

\section{Abbreviations}

C: Celsius; Ct: Cycle threshold; DNA: Deoxyribonucleic acid;

GAPDH: Glyceraldehyde 3-phosphate dehydrogenase; IL-1 $\beta$ : interleukin 1 $\beta$;

LCE1C: Late cornified envelope gene 1C; mRNA: Messenger ribonucleic acid; 
NOS3: Nitric oxide synthase 3; PMI: Post-mortem interval; qRT-PCR: Real-time reverse transcription-polymerase chain reaction; RNA: Ribonucleic acid; $\mathrm{RQ}$ : Relative quantification; $r_{s}$ : Spearman's rank correlation coefficient; SD: Standard deviation; Sec: Second; SPSS: Statistical Package for the Social Sciences; UV: Ultraviolet

\section{Acknowledgements}

None.

\section{Funding}

None.

\section{Availability of data and materials}

The datasets supporting the conclusions of this article are included within the article.

\section{Authors' contributions}

Prof. HE was responsible of the experimental design of the research, starting from the idea, interpretation of results, and critical revision of the paper. Dr. MM gave assistance in writing and final revision. Dr. FH contributed to the experimental work and writing the paper. Prof. AA helped in the final revision of the paper. Prof. DA was responsible for the practical part of the research. All authors read and approved the final manuscript.

\section{Ethics approval}

The experimental work was conducted after the approval of Institutional Animal Care and Use Committee, Faculty of Medicine, Cairo University.

\section{Consent for publication}

Not applicable

\section{Competing interests}

The authors declared that they have no competing interests.

\section{Publisher's Note}

Springer Nature remains neutral with regard to jurisdictional claims in published maps and institutional affiliations.

\section{Author details}

${ }^{1}$ Forensic Medicine and Clinical Toxicology, Faculty of Medicine, Cairo University, Kasr Alainy Street, Cairo 11562, Egypt. ${ }^{2}$ Medical Biochemistry Department, Faculty of Medicine, Cairo University, Cairo, Egypt.

Received: 28 May 2018 Accepted: 28 November 2018

Published online: 13 December 2018

\section{References}

Ali MM, Ibrahim SF, Fayed AA (2017) Using skin gene markers for estimating early postmortem interval at different temperatures. Am J Forensic Med Pathol 8(4):323-325

Bauer M (2007) RNA in forensic science. Forensic Sci Int Genet 1:69-74

Bauer M, Gramlich I, Polzin S, Patzelt D (2003) Quantification of mRNA degradation as possible indicator of postmortem interval-a pilot study. Legal Med 5:220-227

Birdsill AC, Walker DG, Lue L, Sue LI, Beach TG (2011) Postmortem interval effect on RNA and gene expression in human brain tissue. Cell Tissue Bank 12(4): $311-318$

Chan YH (2003a) Biostatistics102: quantitative data-parametric and nonparametric tests. Singapore Med J 44(8):391-396

Chan YH (2003b) Biostatistics 104: correlational analysis. Singapore Med J 44(12): 614-619

Deng W, Lv M, Wang L, Bai P, Liang W, Zhang L (2013) mRNA degradation pattern analysis in post-mortem normalized using the DNA. Forensic Sci Int Genet Suppl Ser 4:266-267

Elghamry HA, Mohamed MI, Hassan FM, Abdelfattah DS, Abdelaal AG (2017) Potential use of GAPDH m-RNA in estimating PMI in brain tissue of albino rats at different environmental conditions. Egypt J Forensic Sci 7:24

Fontanesi L, Colombo M, Beretti F, Russo V (2008) Evaluation of post mortem stability of porcine skeletal muscle RNA. Meat Sci 80:1345-1351

Garg SP, Garg V (2010) Serum enzymes changes after death \& its correlation with time since death. J Ind Acad Forensic Med 32(4):355-357
Inoue H, Kimura A, Tuji T (2002) Degradation profile of mRNA in a dead rat body: basic semi-quantification study. Forensic Sci Int 130:127-132

Li Z, Yang L, Wang J, Shi W, Pawar RA, Liu Y, Xu C, Cong W, Hu Q, Lu T, Xia F, Guo W, Zhao M, Zhang Y (2010) B-Actin is a useful internal control for tissuespecific gene expression studies using quantitative real-time PCR in the halfsmooth tongue sole Cynoglossussemilaevis challenged with LPS or Vibrio anguillarum. Fish \& Shellfish Immunology 29:89-93

Liu YL, Ma KJ, Li WC, Xu HM, Xue AM, Shen YW, Zhou YQ, Zhao ZQ (2011) Estimation of early postmortem interval using beta-actin mRNA in rat's brain, heart and kidney. Fa Yi Xue Za Zhi 27(1):5-8

Lv Y, Ma K, Zhang H, He M, Zhang P, Shen Y, Jiang N, Ma D, Chen L (2014) A time course study demonstrating mRNA, microRNA, 185 rRNA, and U6 snRNA changes to estimate PMI in deceased Rat's spleen. J Forensic Sci 59(5):1286-1294

Lv YH, Ma JL, Pan H, Zhang H, Li WC, Xue AM, Wang HJ, Ma KJ, Chen L (2016) RNA degradation as described by a mathematical model for postmortem interval determination. J Forensic Legal Med 44:43-52

Pan H, Zhang H, Lü YH, Ma JL, Ma KJ, Chen L (2014) Correlation between five RNA markers of rat's skin and PMI at different temperatures. Journal of Forensic Medicine 30(4):245-249

Partemi S, Berne PM, Batlle M, Berruezo A, Mont L, Riuro H, Roig E, Brugada J, Brugada R, Oliva A (2010) Analysis of mRNA from human heart tissue and putative application in forensic molecular pathology. Forensic Sci Int 203:99-105

Sampaio-Silva F, Magalhaes T, Carvalho F (2013) Profiling of RNA degradation for estimation of postmortem interval. PLoS One 8(2):1-8

Sato T, Zaitsu K, Tsuboi K, Nomura M, Kusano M, Shima N, Abe S, Ishii A Tsuchihashi H, Suzuki K (2015) A preliminary study on postmortem interval estimation of suffocated rats by GC-MS/MS-based plasma metabolic profiling. Anal Bioanal Chem 407(13):3659-3665

Song HJ, Choi YL, Kang SY, Chae JM (2012) The effect of elapsed time on the quantity of mRNA in skin: a study to evaluate the potential forensic use of mRNA to determine the postmortem interval. Korean Journal of Legal Medicine 36:151-158

Wen-Can L, Kai-Jun M, Ye-Hui L, Ping Z, Hui P, Heng Z, Hui-Jun W, Duan M, Long C (2014) Postmortem interval determination using 18S-rRNA and microRNA. Sci Justice 54(4):307-310

Young ST, Wells JD, Hobbs GR, Bishop CP (2013) Estimating postmortem interval using RNA degradation and morphological changes in tooth pulp. Forensic Sci Int 229(163):1-6

\section{Submit your manuscript to a SpringerOpen ${ }^{\oplus}$ journal and benefit from:}

- Convenient online submission

- Rigorous peer review

- Open access: articles freely available online

High visibility within the field

- Retaining the copyright to your article

Submit your next manuscript at $\boldsymbol{\nabla}$ springeropen.com 